\title{
ANALISIS KARIOTIPE PADA TANAMAN PISANG TONGKAT LANGIT (Musa troglodytarum L) SERTA SUMBANGAN ILMIAH BAGI MATA KULIAH ANATOMI TUMBUHAN
}

\author{
Prelly M.J. Tuapattinaya ${ }^{1}$ \\ ${ }^{1}$ Staf pengajar Program Studi Pendidikan Biologi Universitas Pattimura \\ Jln. Ir. M. Putuhena, Kampus Poka-Ambon \\ frelly_tuapattinaya@yahoo.co.id
}

\begin{abstract}
Abstrak: Tujuan dari penelitian ini adalah menganalisis kariotipe pada tanaman pisang tongkat langit (Musa troglodytarum L.) dan sumbangan ilmiah bagi mahasiswa yang menawarkan mata kuliah anatomi tumbuhan. Penelitian ini dilaksanakan di Laboratorium Biologi Dasar FKIP Unpatti Ambon. Objek dalam penelitian ini adalah akar sekunder pisang tongkat langit (Musa troglodytarum L.) dengan panjang akar 3-4 $\mathrm{cm}$ yang dipotong pada jam 09.00 WIT. Hasil analisis kariotipe diperoleh hasil bahwa pisang tongkat langit (Musa troglodytarum L.) varietas buah panjang memiliki tiga tipe kromosom yaitu, metesentrik, submetasentrik, dan subtelosentrik, varietas buah pendek memiliki dua tipe kromosom yaitu, metasentrik, dan submetasentrik. Hasil penelitian dijadikan sebagai sumbangan ilmiah dalam bentuk penuntun praktikum mata kuliah anatomi tumbuhan.
\end{abstract}

\section{Kata Kunci: Kariotipe, Pisang Tongkat Langit, Sumbangan Ilmiah.}

Tanaman pisang sebagai salah satu tanaman tropis penghasil buah yang terkenal di masyarakat Indonesia.Tanaman ini menghasilkan buah yang dapat dikonsumsi, baik sebagai buah meja maupun sebagai makanan yang harus diolah lebih dahulu. Terdapat beberapa jenis dan varietas pisang yang tersebar di Indonesia. Jumari, dkk. (2002) menjelaskan bahwa jenis pisang di Indonesia antara lain pisang raja, pisang batu, pisang ambon, pisang kapok, dan pisang lainnya dengan berbagai rasa, fungsi, serta ukuran buah yang berbeda-beda, mulai dari yang berukuran kecil sampai yang berukuran besar.

Propinsi Maluku merupakan salah satu daerah produksi dan wilayah potensial untuk dikembangkan tanaman pisang karena kondisi tanah dan iklim yang cocok. Jenis pisang yang banyak terdapat di pasar-pasar tradisional Maluku antara lain pisang meja, pisang sepatu, pisang tongkat langit, pisang raja, pisang 40 hari, pisang jarum dan beragam jenis yang lainnya. Pisang tongkat langit (Musa troglodytarum L.) merupakan salah satu jenis pisang yang digunakan untuk pengobatan oleh masyarakat Maluku. Pisang ini dinamakan tongkat langit, oleh karena bentuk tandannya yang tegak menengadah ke langit. Kondisi tersebut menjadikan pisang tongkat langit unik dan berbeda dengan jenis pisang-pisang yang lain dimana tandan menghadap ke tanah. Keadaan tandan yang unik pada pisang ini mungkin menyebarkan sulit beradaptasi dan tidak dapat tumbuh dengan baik pada wilayah yang berbeda (Ploetz, et al., 2007).

BIOLOGI SEL (VOL 7 NO 1 EDISI JAN-JUL 2018 ISSN 2252-858X/E-ISSN 2541-1225) PAGE 56 
Pisang ini termasuk sangat tahan terhadap hama dan penyakit. Buah pisang tongkat langit ada yang berukuran panjang dan ada yang berukuran pendek (Heyne, 1988; Valmayor, dkk., 2000; INIBAP, 2002).

Berdasarkan keunikan dan manfaat dari tanaman pisang tongkat langit, maka tanaman pisang ini harus dilestarikan. Upaya pelestarian tanaman dapat dilakukan dengan cara pembudidayaan vegetatif oleh masyarakat, selain itu, pembudidayaan modern juga dapat dilakukan melalui teknik kultur jaringan. Teknik kultur jaringan digunakan untuk memperbanyak jenis tamanan pisang tongkat langit dengan menggunakan bagian jaringan yang memiliki sifat titopotensi. Untuk melakukan hal tersebut, diperlukan informasi secara sitologi terkait dengan kromosomnya. Cara mengungkapkan kromosom tanaman pisang tongkat langit adalah melalui analisis kariotipe, sedangkan informasi dari tanaman ini belum diketahui dan dipublikasi.

Berdasarkan ciri-ciri morfologi kemungkinan pisang tongkat langit digolongkan dalam seksi Australimusa dengan jumlah kromosom (x = 10) dibandingkan dengan seksi tanaman pisang lain yang memiliki jumlah kromosom $(\mathrm{x}=10),(\mathrm{x}=7)$. Penelitian tentang kariotipe pada tanaman pisang telah dilakukan oleh Mailina dkk. (2006) melaporkan bahwa tanaman pisang Mauli memiliki jumlah kromosom sebanyak 22 buah dan dua macam tipe kromosom yaitu metasentrik 7 pasang dan submetasentrik ada 4 pasang. Damayanti (2007) melaporkan bahwa pada tanaman pisang asal Kalimantan Timur yang jumlah kromosom pada sel somatik terhadap enam aksesi plasma nutfah pisang asal Kalimantan timur adalah 22 dan 33. Untuk kariotipe tanaman pisang tongkat langit belum pernah dilakukan.

Setelah mengetahui kariotipe dari pisang tongkat langit, maka hasil penelitian dapat memberikan sumbangan ilmiah bagi mahasiswa yang mempelajari matakuliah anatomi tumbuhan. Mata kuliah anatomi tumbuhan mempelajari tentang sel dan sifat, ciri, serta fungsi jaringan penyusun tubuh tumbuhan tingkat tinggi. Selama ini praktikum mata kuliah anatomi tumbuhan berorientasi pada pengamatan sifat dan ciri jaringan tumbuhan, serta benda ergastik dan isi sel yang berada pada tubuh tumbuhan. Oleh karena itu, melalui hasil penelitian dapat menyumbangkan hasil penelitian berupa pengamatan jaringan meristem tumbuhan untuk dijadikan sebagai salah satu topik praktikum pada mata kuliah anatomi tumbuhan. Tujuan dari penelitian ini adalah menganalisis kariotipe pada tanaman pisang Tongkat Langit (Musa troglodytarum L.) dan sumbangan ilmiah bagi mahasiswa yang menawarkan mata kuliah anatomi tumbuhan.

\section{METODE PENELITIAN}

Penelitian ini merupakan penelitian kualitatif yang bertujuan untuk menganalisis dan mendeskripsikan kariotipe pisang tongkat langit. Penelitian ini dilakukan Laboratorium Biologi Dasar FKIP Unpatti Ambon. Objek dalam penelitian ini adalah 
ujung akar pisang tongkat langit (Musa troglodytarum L.) dengan panjang 3-4 cm. Alat yang digunakan dalam penelitian ini adalah: mikroskop cahaya, kaca benda dan kaca penutup, pinset, petridish, silet tajam, pembakar spiritus dan korek api, mistar, kamera digital. Bahan yang digunakan dalam penelitian ini adalah:ujung akar pisang tongkat langit, tisu, aquades, asam asetat, HCL $1 \mathrm{~N}$, aseto orcein. Analisis kariotipe pisang tongkat langit dimulai dengan tahapan sebagai berikut:

1. Pemisahan: ujung akar sekunder dari anakan pisang tongkat langit dipotong dengan panjang sekitar 3-4 cm pada pukul 09.00 WIT.

2. Pelaksanaan

a. Siapkan alat dan bahan yang diperlukan

b. Pra perlakukan: dilakukan perendaman bahan dalam air suling selama 24 jam pada suhu $5^{0} \mathrm{C}-8^{0} \mathrm{C}$

c. Fiksasi: pada tahap ini ujung akar dipotong 3-4 cm, masukan ke dalam cawan petri yang berisi larutan HCL $1 \mathrm{~N}$ biarkan selama \pm 10 menit.tujuan dari fiksasi yaitu untuk mematikan jaringan pada akar.

d. Pencucuian: irisan akar yang telah di fiksasi kemudian dicuci dengan menggunakan aquades sebanyak tiga kali, pencucian bertujuan untuk menghilangkan pengaruh perlakukan sebelumnya.

e. Pewarnaan: ujung akar direndam dalam acetic-orcein $2 \%$ selama 24 jam pada suhu $5^{0} \mathrm{C}-10^{0} \mathrm{C}$

f. Squashing :

- Bagian ujung akar meristem diambil $\pm 0,5 \mathrm{~mm}$ dan diletakan pada kaca objek.

- Ujung akar diletakkan pada kaca objek kemudian ditetesi dengan asam asetat tutup dengan cover glass.

- Kemudian dipencet sehingga ujung akar menjadi sangat pipih.

- Agar cover glas tidak bergerak, dapat ditutupi dengan cat kuku/cutex.

- Pengamatan preparat ujung akar di bawah mikroskop.

- Preparat ini kemudian digunakan untuk pengamatan kariotipe.

g. Pengamatan Kariotipe menurut Syukur, dkk. (2006) dan menggunakan program Smart Kariotipe sebagai berikut:

- Perbesar foto preparat.

- Tandai setiap kromosom dengan nomor yang berbeda gunting tiap kromosom berdasarkan nomor yang telah diberikan.

- Ukurlah lengan panjang dan lengan pendek kromosom kemudian, hitung panjang total kromosom dan rasio antara lengan panjang dan pendek.

- Tempatkan data tentang panjang total dan rasio panjang lengan dari setiap kromosom pada diagram pencar (scatter plot), dengan sumbu $\mathrm{X}=$ rasio lengan panjang dan lengan pendek; sumbu $\mathrm{Y}=$ panjang total kromosom 
- Pasangkanlah kromosom yang terletak berdekatan pada diagram pencar tersebut

- Urutkan pasangan kromosom berdasarkan panjang total kromosom dari yang terbesar sampai yang terkecil dan rasio panjang lengan dari yang terkecil sampai yang terbesar. Panjang total dan rasio panjang lengan dari sepasang kromosom merupakan nilai rata - rata dari kedua kromosom.

- Tentukan tipe kromosom dengan rasio panjang lengan (C):

1. $1,0 \leq \mathrm{C}<1,7=$ Kromosom metasentrik

2. $1,7 \leq \mathrm{C}<3,6=$ Kromosom submetasentrik

3. $3,0 \leq \mathrm{C}<7,0=$ Kromosom subtelosentrik

4. $\geq 7,0=$ Kromosom telosentrik

Data dalam penelitian ini berupa data kualitatif. Analisis data dalam penelitian ini secara deskriptif untuk menganalisis kariotipe pada taman pisang tongkat langit (Musa troglodytarum L.)

\section{HASIL DAN PEMBAHASAN}

\section{Pengamatan kromosom Pisang Tongkat Langit (Musa troglodytarum L.)}

Penelitian mengenai analisis kariotipe ujung akar pisang tongkat langit (Musa troglodytarum L.) diawali dengan pengamatan kromosom pisang tongkat langit dengan dua varietas yang berbeda yaitu buah pendek dan buah panjang menggunakan mikroskop cahaya dengan perbesaran 1000X. Hasil pengamatan kromosom pisang tongkat langit (Musa troglodytarum L.) varietas buah pendek dan buah panjang dapat dilihat pada gambar 1 dan2 berikut ini.
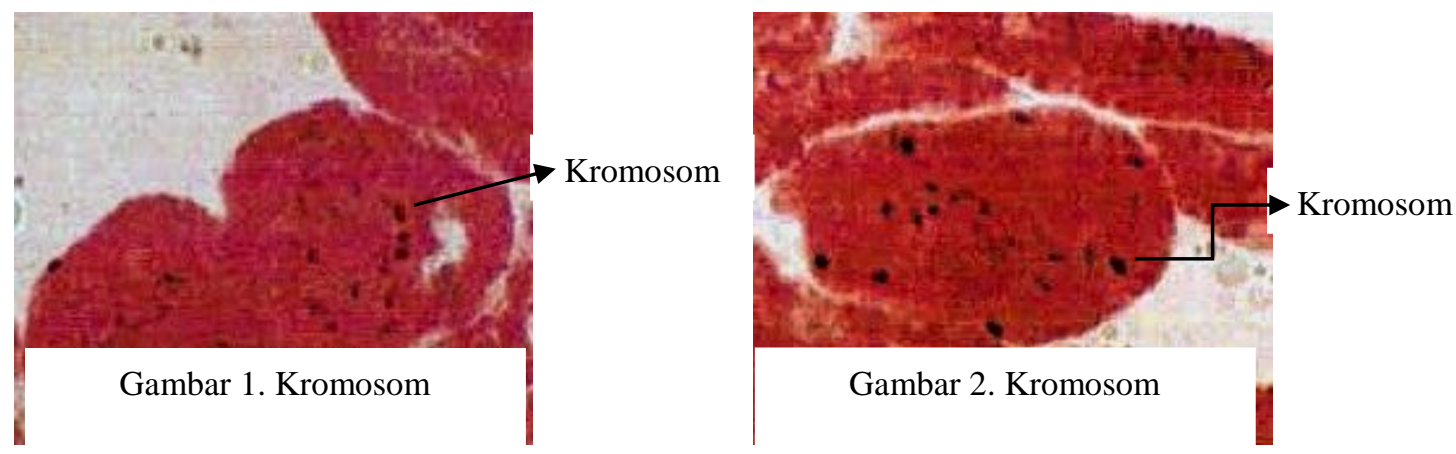

\section{Analisis Kariotipe}

Berdasarkan pengamatan terhadap kromosom pisang tongkat langit (Musa troglodytarum L.) buah pendek dan buah panjang maka dilanjutkan dengan analisis kariotipe pisang tongkat langit (Musa troglodytarum L.) meliputi jumlah, ukuran, bentuk. Hasil analisis kariotipe pisang tongkat langit (Musa troglodytarum L.) varietas buah pendek dan buah panjang dapat dilihat pada Gambar 3 dan 4 berikut ini. 


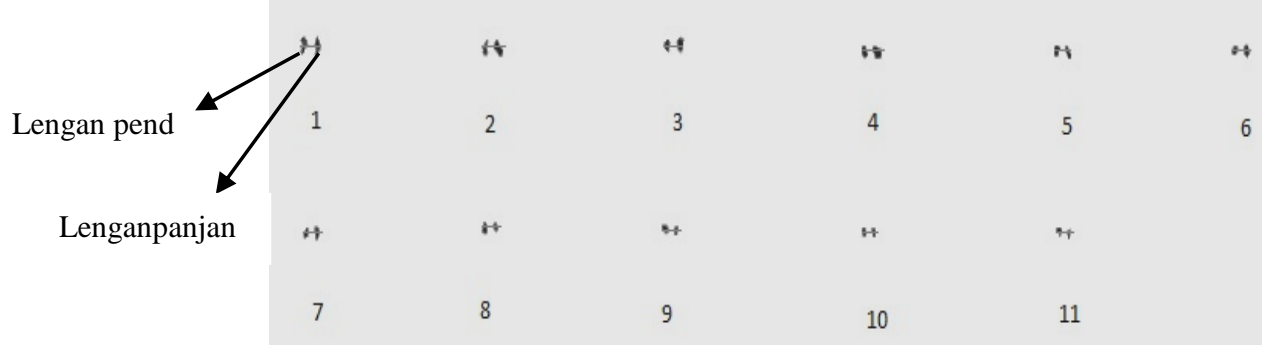

Gambar 3 kariotipepisang tongkat langit buah pendek

Hasil pengukuran panjang lengan panjang dan panjang lengan pendek yang telah dibuat dalam gambar 3 memperlihatkan bahwa panjang total kromosom pisang tongkat langit berkisar antara 0,8-3,2 $\mathrm{mm}$. Kisaran panjang lengan panjang berkisar antara 0,51,9 mm, sedangkan kisaran panjang lengan pendek adalah 0,3-1,3 mm. Dari hasil pengukuran panjang lengan kromosom pisang tongkat langit yang dilakukan peneliti maka didapat dua tipe kromosom yaitu 4 kromosom metasentrik dan 18 kromosom submetasentrik.

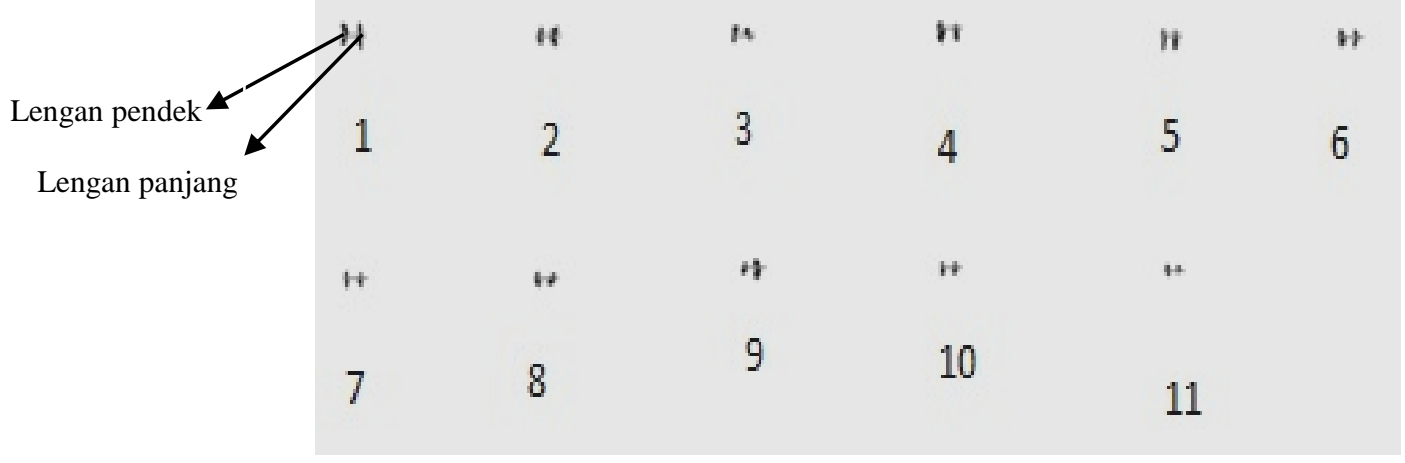

Gambar 4. Kariotipe pisang tongkat langit buah panjang

Hasil pengukuran panjang lengan panjang dan panjang lengan pendek yang telah dibuat dalam gambar 3 memperlihatkan bahwa panjang total kromosom pisang tongkat langit berkisar antara 0,3-3,0mm. Kisaran panjang lengan panjang berkisar antara 0,21,7 mm, sedangkan kisaran panjang lengan pendek adalah 0,1-1,3 mm. Dari hasil pengukuran panjang lengan kromosom pisang tongkat langit yang dilakukan peneliti maka didapat tiga tipe kromosom yaitu 11 kromosom metasentrik dan 10 kromosom submetasentrik dan 1 kromosom subtelosentrik.

Berdasarkan hasil penelitian yang telah dilakukan, diketahui bahwa jumlah kromosom pisang tongkat langit (Musa troglodytarum L.) adalah $\mathrm{n}=11(2 \mathrm{n}=22)$. Hal ini sejalan dengan data dari International Network for the Improvement of Banana and Plantain (2002) bahwa jumlah kromosom dasar pisang adalah $\mathrm{x}=11$ serta diperkirakan genom haploid pisang hanya sekitar 500-600 Mb.

BIOLOGI SEL (VOL 7 NO 1 EDISI JAN-JUL 2018 ISSN 2252-858X/E-ISSN 2541-1225) PAGE 60 
Setelah diperoleh jumlah dan ukuran kromosom pisang tongkat langit (Musa troglodytarum L.) buah panjang dan pendek maka dapat disusun kariotipenya. Menurut Elrod dan Stansfield (2002) kariotipe adalah pengaturan dan penyusunan kromosom secara standar berdasarkan panjang, jumlah serta bentuk kromosom dari suatu organisme. Pengamatan kromosom dan analisis kariotipe dilakukan pada jaringan meristem yakni ujung akar pisang tongkat langit (Musa troglodytarum L.) yang dipotong pada pukul 09.00 pagi WIT. Hal ini dilakukan karena pada jam 09.00 merupakan waktu mitosis akar pisang tongkat langit (Musa troglodytarum L.) buah panjang dan pendek. Hasil yang didapat dalam penelitian ini yakni kromosom yang berada pada tahap prometafase dan metafase. Hal ini sesuai dengan pendapat Starr (2001) bahwa dengan melakukan analisis secara fisik dapat juga dilihat gambaran mikroskopis kromosom kelamin dan kromosom tubuh pada metafase dari proses mitosis.

Berdasarkan hasil penelitian ini peneliti menemukan beberapa bentuk kromosom dari kedua varietas pisang tongkat langit yaitu submetasentrik, metasentrik, dan subtelosentrik. Metasentrik adalah kromoson yang sentromernya membagi lengan kromoson sama panjang sehingga bentuknya seperti huruf V. Submetasentrik adalah kromoson yang letak sentromernya dekat dengan tengah kromosom yang demikian memiliki bentuk seperti huruf L. Subtelosentrik adalah kromosom yang sentromernya yang terletak di ujung kromosom sehingga hanya memiliki satu lengan. Dari hasil tersebut peneliti dapat menjelaskan bahwa, antara kedua varietas Musa troglodytarum L. yang berbuah panjang dan berbuah pendek terdapat sedikit perbedaan dilihat dari jumlah, tipe/bentuk kromosom. Pisang buah panjang memiliki tiga (3) tipe kromosom yaitu, metesentrik, submetasentrik, dan subtelosentrik, sedangkan,pisang buah pendek memiliki dua (2) tipe kromosom yaitu, metasentrik, dan submetasentrik. Perbedaan tipe kromosom pada pisang tongkat langit (Musa troglodytarum L.) varietas buah pendek dan buah panjang ini sesuai pendapat Suryo (2008) bahwa tipe kromosom yang terdapat pada suatu spesies tidak selalu sama.

Dari hasil pengukuran panjang lengan kromosom pisang tongkat langit yang dilakukan peneliti tidak terlalu mengalami perbedaaan dengan penelitian pada pisangpisang sebelumnya. Pada umumnya jumlah kromosom pada pisang banyak dan ukurannya kecil, sehingga kromosom yang didapat dari hasil penelitian pada pisang tongkat langit ini juga ukurannya kecil sehingga sedikit mengalami kesulitan bagi peneliti dalam meganalisa kromosom pisang tersebut.

Menurut Mailina, dkk. (2006) penelitian pada pisang Mauli mempunyai ukuran yang bervariasi, dimana ukuran lengan panjang berkisar antara $1,38 \mu \mathrm{m}-0,5 \mu \mathrm{m}$, ukuran lengan pendek berkisar antara $1,00 \mu \mathrm{m}-0,45 \mu \mathrm{m}$ sedangkan total panjang lengan kromosom berkisar antara $2,38 \mu \mathrm{m}-0,95 \mu \mathrm{m}$. Tipe kromosom yang dijumpai pada pisang ini ada dua macam, yaitu metasentrik 7 pasang dan submetasentrik ada 4 pasang.

BIOLOGI SEL (VOL 7 NO 1 EDISI JAN-JUL 2018 ISSN 2252-858X/E-ISSN 2541-1225) PAGE 61 
Pada pengamatan kromosom ujung akar pisang tongkat langit (Musa troglodytarum L.) terlihat bahwa kurang adanya perbedaan antara kedua varietas pisang tersebut, umumnya kromosom kedua jenis pisang tongkat langit tersebut menyebar dengan ukuran yang sangat kecil karena jumlahnya yang cukup banyak.Untuk perbedaan yang sangat menonjol dari kedua varietas pisang tongkat langit tersebut kurang ada perbedaan bahkan ukuran dan bentuk kromosomnya pun tidak jauh berbeda.

Penuntun praktikum ini merupakan bentuk sumbangan ilmiah pada pembelajaran mata kuliah Anatomi Tumbuhan.Penuntun praktikum yang disusun ini mengacu pada pembelajaran problem based learning. Konsep belajar problem based learning tersebut adalah belajar melalui penemuan atau discovery learning. Ibrahim dan Nur dalam Rusman (2010) menjelaskan bahwa problem based learning merupakan suatu pendekatan pembelajaran yang digunakan untuk merangsang berpikir tingkat tinggi siswa dalam situasi yang berorientasi pada masalah dunia nyata, termasuk di dalamnya belajar bagaimana belajar. Oleh karena itu, penuntun praktikum Anatomi Tumbuhan ini bersifat kontekstual dan mengangkat potensi daerah Maluku, karena bersumber dari hasil-hasil penelitian tentang analisis kariotipe pisang tongkat langit (Musa troglodytarum L.). Menurut Muslich (2009) salah satu strategi yang menunjang pembelajaran kontekstual ialah memanfaatkan lingkungan siswa untuk memperoleh pengalaman belajar. Penuntun praktikum ini mencerminkan tanaman pisang tongkat langit (Musa troglodytarum L.) sebagai lingkungan belajar untuk pengamatan jaringan meristem pisang tongkat langit (Musa troglodytarum L.) bagi mahasiswa, karena pada dasarnya mahasiswa telah mengenal pisang tongkat langit ini.

\section{KESIMPULAN}

1. Jumlah kromosom pada pisang tongkat langit yang berbuah panjang dan yang berbuah pendek adalah sama.

2. Kariotipe pada pisang tongkat langit yang berbuah panjang yaitu 0,3-3,0 $\mathrm{mm}$ dan yang berbuah pendek yaitu 0,8-3,2 $\mathrm{mm}$.

3. Kromosom yang ditemukan adalah 22 pasang dan 3 bentuk kromosom yaitu metasentrik, submetasentrik dan subtelosentrik.

\section{SARAN}

Diharapkan untuk melakukan kajian yang lebih mendalam tentang kariotip[e pisang tongkat langit dengan menggunakan sekuensin DNA.

\section{DAFTAR PUSTAKA}

Damayanti, F. 2007. Analisis Jumlah Kromosom Dan Anatomi Stomata Pada Beberapa Plasma Nutfah Pisang (Musa SP) Asal Kalimantan Timur. Skripsi Jurusan Biologi FMIPA. Universitas Mulawarman. Samarinda.

Elrod, S. Dan W. Stansfield. 2002. Genetika, Edisi Keempat. Erlangga: Jakarta. 
Heyne, K. 1988. Tumbuhan Berguna Indonesia I. Balai Penelitian dan Pengembangan Kehutanan, Departemen Kehutanan.

International Network for the Improvement of Banana and Plantain (INIBAP). 2002. A Strategy for the Global Musa Genomics Consortium. Report of a meeting held in Arlington, USA, 17-20Jul 2001. Montpellier, hlm 1-43.

Jumari, Utami. S., Wiryani, E. 2002. Identifikasi Plasma Nutfah Pisang di Semarang Jawa Tengah. UNDIP Press. Semarang.

Mailina Yulianti, Eny Dwi Pujawati, Badruzsaufari, 2006. Analisis Kariotipe Pisang Mauli. Skripsi Fakultas MIPA, Universitas Lambung Mangkurat Kalimantan Selatan.

Muslich, M. 2009. Kurikulum Tingkat Satuan Pendidikan. Pembelajaran Berbasis Kompetensi dan Kontekstual. Cetakan kelima. Bumi Aksara: Jakarta

Ploetz, C. Randy, A.K. Kepler, J. Danielis, Scot C. Nelson. 2007. Species Profiles for Pacific Island Agroforestry.www.traditionaltree.org.

Rusman. 2010. Model-Model Pembelajaran. PT Rajagrafindo Persada: Jakarta.

Starr, C. 2001. Cell Biology and Genetics. Ninth Edition. Lisa Biological Illustrator, United Stated of America.

Syukur, M., S. Sastrosumarjo, Y. Wahyu, S.I. Aisyah, S. Sujiprihati, R. Yunianti. 2006. Sitogenetika Tanaman. IPB Press: Bogor.

Suryo. 2008. Genetika Strata I. Gadja mada University Press: Yogyakarta

Valmayor, R. V., B. Silayoi , S. H. Jamaluddin, S. Kusumo, L.D. Danh, R.R. C. Espino \& O.C. 2000. Banana Cultivar Names and Synonyms In Southeast Asia. INIBAB. Asia Pasifik. Los Banos. Laguna. Filipin 